[Agr. Biol. Chem., Vol. 26, No. 1, p. 49 55, 1961]

\title{
Urocanic Acid Production by Sporogenous Bacteria
}

\author{
Part II. Cultural Conditions and Mechanisms of Urocanic Acid \\ Accumulation \\ By Hiroshi Imanaka \\ Tokyo Research Laboratory of Fujisawa Pharmaceutical Industries, Ltd., Tokyo \\ Received October 11, 1961
}

\begin{abstract}
As the results of a screening of several type cultures of bacteria, Bacillus subtilis var. thermophilus was revealed to be the most powerful strain for urocanic acid production. The accumulation of urocanic acid by this bacteria is caused by deamination of L-histidine, and is particularly accelerated in the presence of a component (X-factor) in meat extract. In the decomposition of urocanic acid the optimal pH of urocanase activity is markedly inhibited by the deviation of $\mathrm{pH}$ of the culture medium. The histidase of this bacteria is supposed to be a new exo-type enzyme.
\end{abstract}

\section{INTRODUCTION}

In the previous paper'), it was reported that sporogenous bacteria, which the author named Bacillus subtilis var. thermophilus, produced a significant amount of urocanic acid in culture media. Several authors ${ }^{2 \sim 5}$ ) have reported the isolation of urocanic acid from urine and some other biological sources. Sera $^{6)}$ and others ${ }^{7,8)}$ stated that histidine could be converted to urocanic acid in good yields using purified liver preparation, and this conversion was also successfully made using histidine-adapted cell of Pseudomonas fluorescens by Tabor and Hayashi ${ }^{9)}$. However, the information on the accumulation of

1) H. Imanaka, T. Miyoshi and H. Sakai, This Journal, 25, 680 (1961)

2) M. Jaffe, Ber, 7, 1669 (1874).

3) S. Ota, Osaka Daigaku Igaku Zassi, 8, 439 (1956)

4) B. Magasanik, J. Biol. Chem., 205, 1019 (1953).

5) H. Tristman, J. Gen. Microbiol., 23, 425 (1960).

6) Y. Sera, Osaka Univ. Med. J., 4, 1 (1951).

7) Y. Oyamada, J. Biochem, (Japan), 36, 227 (1944) .

8) D.A. Hall, Biochem. J., 51, 499 (1952).

9) H. Tabor, and O. Hayashi, J. Biol. Chem., 194, 171 (1952). urocanic acid in culture media of microorganisms could not hitherto be found. The present paper concerns the studies on cultural conditions and the mechanisms of urocanic acid production.

\section{EXPERIMENTAL METHODS}

\section{1) Strains.}

Bacillus subtilis var. thermophilus N-10 stored on bouillon agar slant was used as inoculum. Ps. fluorescens and other bacteria used in this experiment were supplied from the culture collection of our laboratory. 2) Cultivation.

The compositions of medium used in this experiment are shown in Table I. Each $100 \mathrm{ml}$ of medium poured into $500 \mathrm{ml}$ shaking flasks or $10 \mathrm{ml}$ in $25 \mathrm{ml}$. $\mathrm{T}$ flasks, cotton plugged and sterilized in autoclave under $1.5 \mathrm{~atm}$ pressure for 15 minutes. Incubation was carried out on reciprocating machines at $37^{\circ} \mathrm{C}$.

\section{3) Analytical Methods.}

a) L-Histidine. L-Histidine was separated by paper chromatography using mixture of $n$-butanol, acetic acid and water $(4: 1: 2)$ as developing solvent and the spot was detected by ninhydrin reagent. -The fraction of L-histidine on paper chromatography was 
TABle I. Composition of Media

Bouillon medium

meat extract

polypeptone

$\mathrm{NaCl}$

glucose

$\mathrm{pH} \quad 7.2$

Basal medium

$\begin{array}{ll}\text { glucose } & 1 \% \\ \mathrm{NH}_{4} \mathrm{Cl} & 0.25 \\ \mathrm{NH}_{4} \mathrm{NO}_{3} & 0.5 \\ \mathrm{MgSO}_{4} \cdot 7 \mathrm{H}_{2} \mathrm{O} & 0.05 \\ \mathrm{CaCl} \cdot 2 \mathrm{H}_{2} \mathrm{O} & 0.0025 \\ \mathrm{~K}_{2} \mathrm{HPO}_{4} & 0.3 \\ \mathrm{KH}_{2} \mathrm{PO}_{4} & 0.15 \\ \mathrm{Na}_{2} \mathrm{SO}_{4} & 0.05 \\ \text { asparagine } & 0.07 \\ \text { trace element solution } & 0.25 \mathrm{ml} / 1000 \mathrm{ml} . \\ \text { pH 7.0 } & \end{array}$

cut off and eluted with $0.1 \mathrm{~N}$ hydrogen chloride. $\mathrm{L}$ histidine in this eluted solution was determined colorimetrically ${ }^{10)}$ at $480 \mathrm{~m}_{\mu}$ by Pauly's ${ }^{11)}$ reagent.

b) Urocanic acid. Urocanic acid was separated by the same technique and was detected under ultraviolet lamp. A fraction of urocanic acid on a paper strip was cut off and eluted with $0.1 \mathrm{~N}$ sodium hydroxide. Urocanic acid in this eluted solution was determined by spectrophotometer at $282.5 \mathrm{~m} \mu$.

\section{4) Determination of Growth Rate.}

The growth rate of the culture was determined by weight of dried cell or sometimes by turbidimetric method.

\section{RESULTS AND DISCUSSIONS}

1) Screening of Urocanic Acid Production by Several Species of Bacteria.

Some type cultures of bacteria were tested of production of urocanic acid in culture media, according to the methods described above. The results were shown in Table II. Although several workers ${ }^{3,4,9)}$ had demonstrated that resting cells or cell-free preparations of Pseudomonas and Aerobacter converted histidine to urocanic acid, the present data pointed out that these bacteria could produce only a little urocanic acid compared with $B$.

\footnotetext{
10) H.T. Macpherson, Biochem. J., 40, 470 (1946)
}

11) H. Pauly, Z. Physiol. Chem., 42, 508 (1904).
Table II. Amount of Urocanic ACID Produced BY SOME TYPICAL BACTERIA

Escherichia coli max. amount of UA*

Proteus vulgaris

Pseudomonas aeruginosa

0

Pseudomonas fuorescens

0

Aerobacter aerosgenes

150

Serratia marcesens

70

Bacillus subtilis

Staphylococcus aureus

Bacillns cereus

100

0

Bacillus brevis

100

Sarcina lutea

110

Micrococcus flavus

Flavobacterium fuscum

Brevibacterium saccharolyticum

Bacillus Subtilis var. thermophilus 750

* UA: urocanic acid.

subtilis var. thermophi!us.

2) Studies on Nitrogen Sources.

As nitrogen sources, $20 \mathrm{~g}$ of corn steep liquor, soy bean mean extract (extracted with $0.1 \mathrm{~N}$ sodium hydroxide in boiling water for 60 minutes from $20 \mathrm{~g}$ of soy bean meal), dried

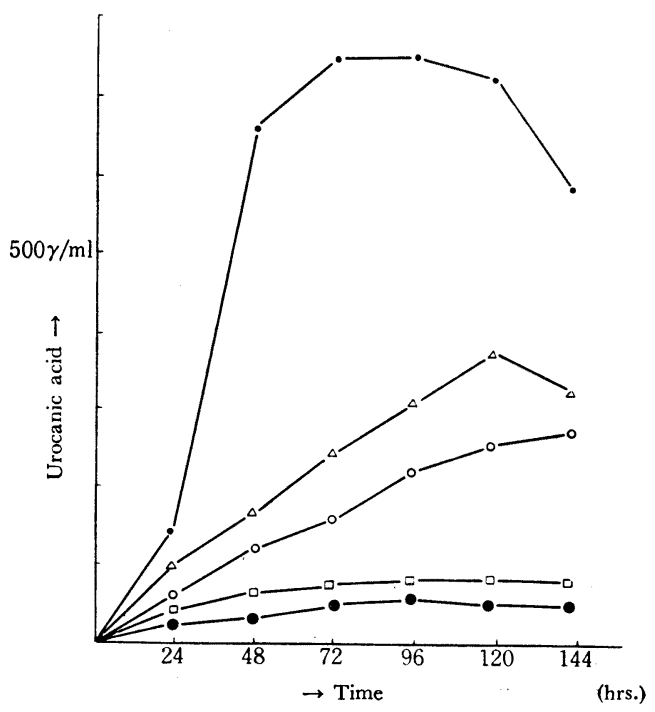

FIG 1. Effects of Various Nitrogen Sources.

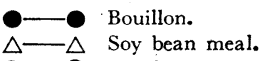

$\square-\square$ Casamino acid.

$\triangle-\triangle$ Soy bean meal

$\bigcirc-\bigcirc$ Corn. Steep Liquor. 


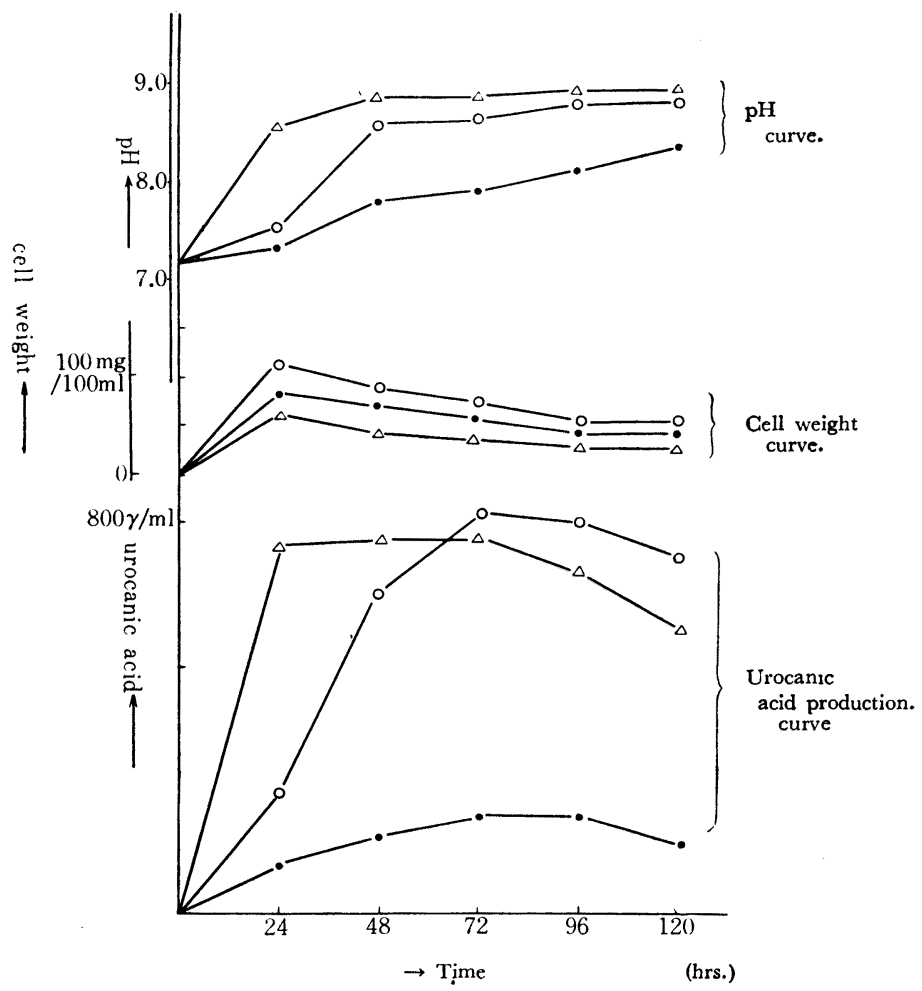

FIG 2. Effects of Bouillon Medium Components.

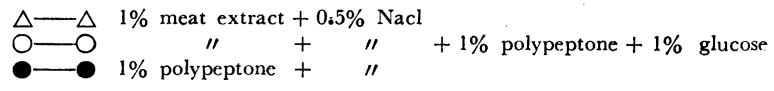

yeast extract (extracted with boiling water for 60 minutes from $10 \mathrm{~g}$ of dried yeast), and $10 \mathrm{~g}$ of casamino acid (Difico) were added to $1000 \mathrm{ml}$ of basal medium (Table I) for screening of composition of medium. And, as shown in Fig. 1, the best result was obtained using bouillon medium. Then, the three substances which compose the bouillon medium were examined of their influences on urocanic acid production. The result in Fig. 2 indicated that meat extract was the most important component for urocanic acid production and its optimal concentration was proved to be $5 \%$ (Fig. 3). The advantage of meat extract for urocanic acid production would be understood by the presence of con- siderable amount of histidine in meat extract.

3) Studies on the Synthetic Media for Urocanic Acid Production.

To elucidate the mechanism of urocanic acid production, a synthetic medium containing L-histidine or urocanic acid was examined using B. subtilis $\mathrm{N}-10$ and Ps. florescens. The results were shown in Fig. $4 \mathrm{~A} \sim \mathrm{C}$. Ps. fluorescens metabolized $\mathrm{L}$-histidine and urocanic acid very rapidly, though $B$. subtilis degraded urocanic acid rather slowly. And the accumulation of urocanic acid is markedly less in the synthetic medium than in the bouillon medium. From these observations, the author assumed the presence of a factor in meat extract by which the accumulation of urocanic 


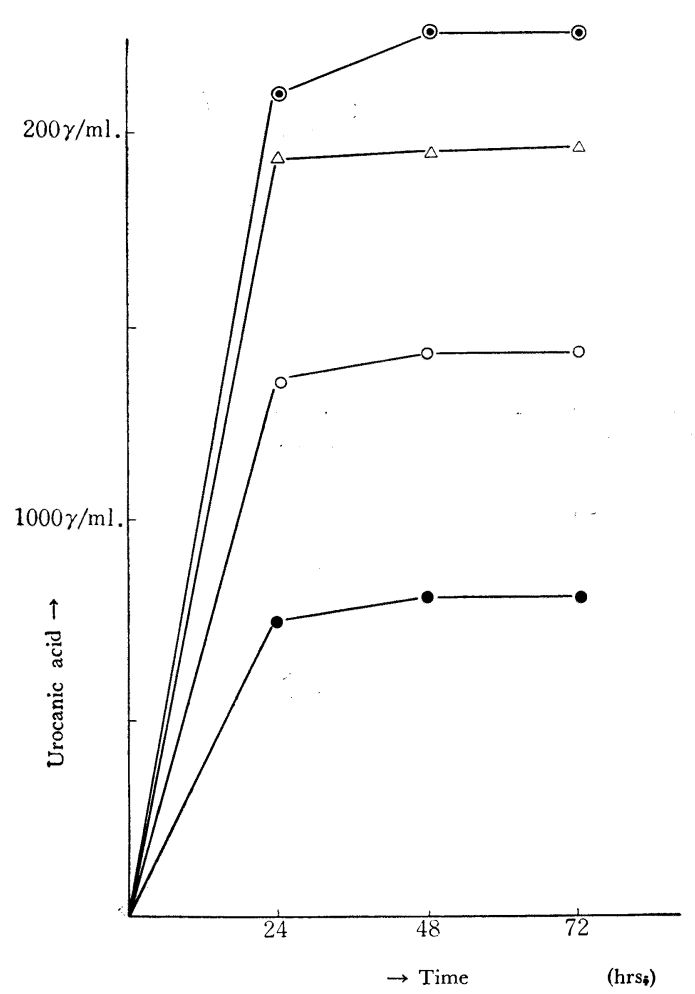

FIG 3. Effects of Concentration of Meat Extract. Incubation was carried out in meat extract containing $0.5 \% \mathrm{Nacl}$ at $37^{\circ} \mathrm{C}$.

○- $5 \%$ meat extract.

$\triangle-\triangle 7 \% \quad \prime \prime$

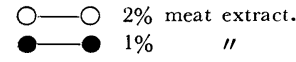

acid from histidine is markedly accelerated. This factor, tentatively named. X-factor, was isolated from meat extract according to the fractionating method shown in Fig. 5. The crude concentrated X-factor solution was revealed to have specific activity to $B$. subtilis but not to Pseudomonas (Table III). As the $\mathrm{X}$-factor concentrate showed ninhydrin positive reaction, the author tried to find out replacement activity of many sorts of amino acids and related compounds. Here, B. subtilis was incubated in the basal medium containing $0.1 \%$ histidine and $0.05 \%$ of test samples, and the results were shown in Table IV. Although the compound which is able to replace completely X-factor corld not be de-

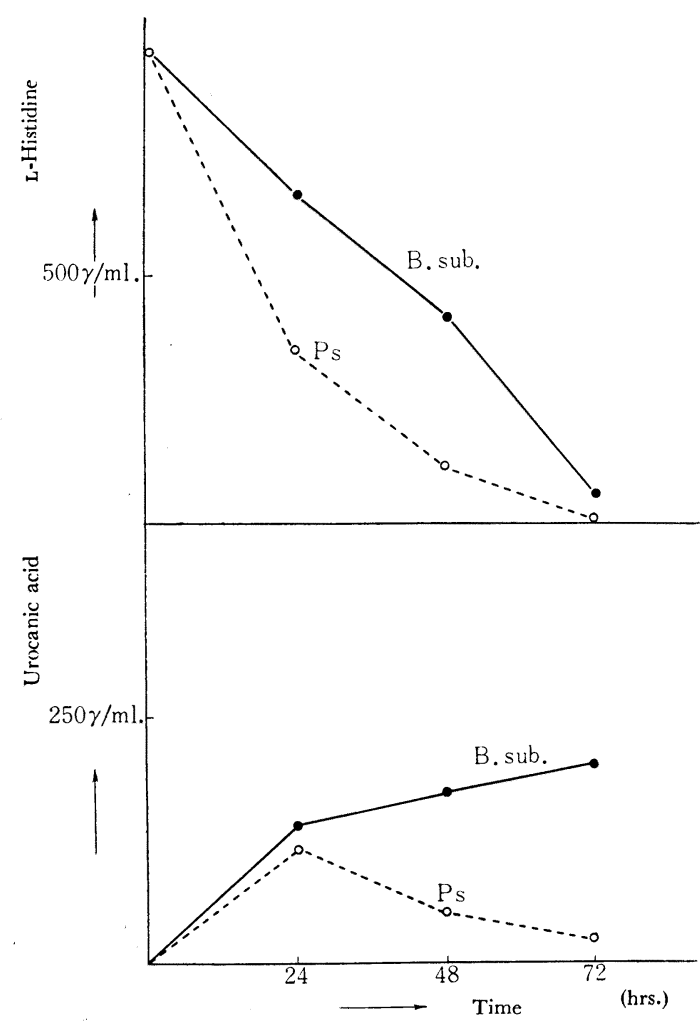

FIG. 4-A. L-Histidine Consumption Curve in the Synthetic Media Containing L-Histidine.

FIG. 4-B. Urocanic Acid Production Curve in the Synthetic Media Containing L-Histidine.

tected, the following compounds-L-glutamine, L-asparatic acid, DL-ornithine, L-arginine, L-alanine, and L-histamine-were found to be effective to some degree. It is an interesting fact that ornithine cycle members showed good effects for urocanic acid production. This favorable effect was confirmed not to be the results of growth promoting action.

4) Urocanic Acid Production by Resting Cell.

The resting cell of $B$. subtilis $\mathrm{N}-10$ was harvested from fermented broth of basal medium containing either $0.1 \%$ L-histidine or $0.1 \%$ urocanic acid. Each resting cell was incubated in phosphate buffer and tris buffer solution of various $\mathrm{pH}$ containing $\mathrm{L}$-histidine or urocanic acid as substrate. As shown in Fig. 6, 


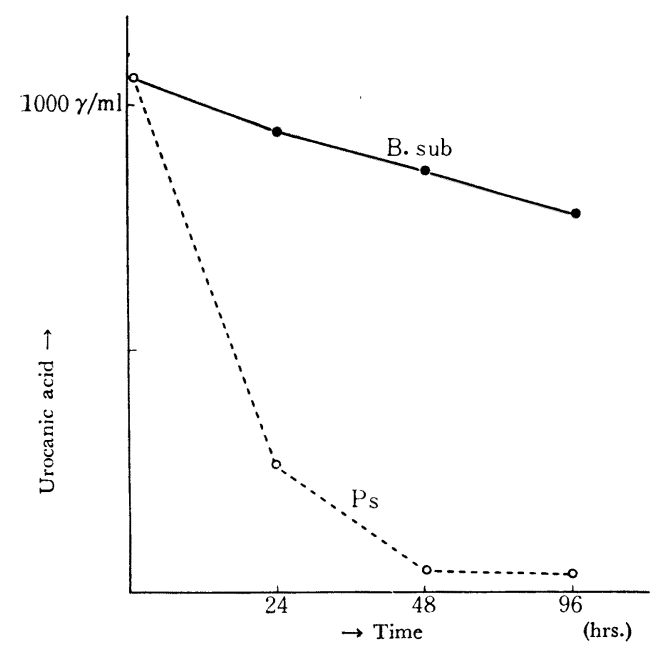

Fig. 4-C. Urocanic Acid Consumption Curve in the Synthetic Media Containing Urocanic Acid.

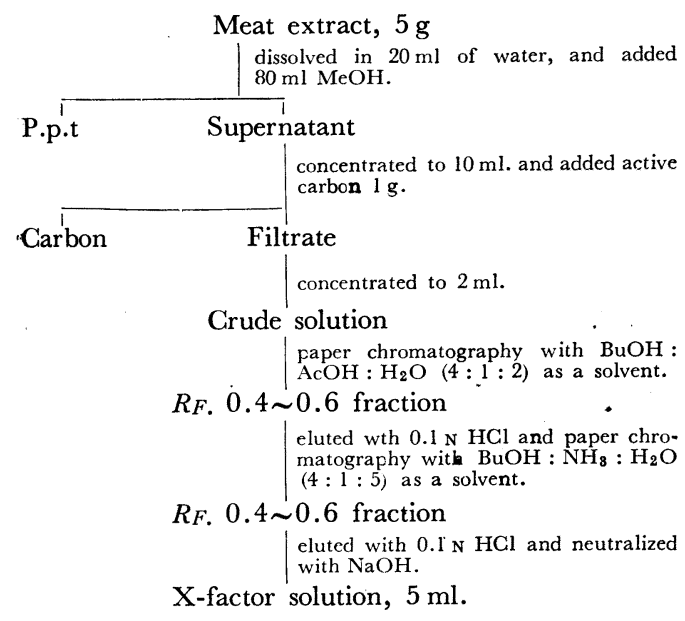

FIG. 5. Fractionation of X-factor.

the cells cultured in presence of L-hitsidine possessed both histidase and urocanase activity, but the cells cultured in presence of urocanic acid possessed urocanase but not histidase. These results suggested histidase and urocanase were produced by adaptation to histidine. The fact agreed with the theory of Magasanik ${ }^{12}$.

12) B. Magasanik, J. Bact., 75, 253 (1957).
TABLE III. EFFECTS OF X-FACTOR UROCANIC ACID PRODUCTION

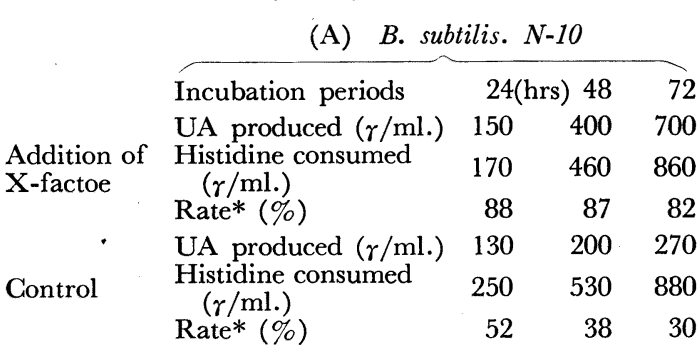

(B) Ps. fluorescens

UA produced $(r / \mathrm{ml}) \quad 110 \quad 80 \quad$.

$\begin{array}{lllll}\text { A-factor } & \begin{array}{l}\text { Histidine consumed } \\ (\gamma / \mathrm{ml} .)\end{array} & 650 \quad 800 & 930\end{array}$

$\begin{array}{llll}\text { Rate* }(\%) & 18 & 10 & 5.4\end{array}$

UA produced $(r / \mathrm{ml}) \quad 150 \quad 70 \quad$.

Control Histidine consumed $700 \quad 810 \quad 930$

$\begin{array}{crrr}(r / \mathrm{ml} .) & 21 & 7.6 & 5.4\end{array}$

* Rate is urocanic acid produced fer histidine consumed. Incubation is carried out in basal medium contg. $0.1 \%$ L-histidine monohydrochloride at $37^{\circ} \mathrm{C}$.

$1 \mathrm{ml}$. of X-factor solution is added to $100 \mathrm{ml}$. of synthetic medium.

The optimal $\mathrm{pH}$ of histidase and urocanase are $8.2 \sim 8.8$ and $7.0 \sim 7.5$, respectively. This difference of optimal $\mathrm{pH}$ value may explain the accumulation of urocanic acid in broth of $B$. subtilis, since the $\mathrm{pH}$ value of the culture media of this bacteria rises up to $\mathrm{pH} 8.5$ or sometimes more (Fig. 2). When filtrates of culture broth (fermentation periods $24 \mathrm{hrs}$ ) were saturated with ammonium sulfate, the precipitated fraction had very strong histidase (optimal pH 8.5 8.8) but not urocanase. From this fact, histidase of this organism was assumed to be a new exo-type enzyme, as the amino acid deaminases so far described were all known as endo-enzymes. The detailed studies of this new enzyme will be reported in the subsequent paper.

\section{SUMMARY}

1) In consequence of screening of several type cultures of bacteria, B. subtilis var. thermophilus was revealed to be the most powerful strain for urocanic acid production. 
TABLE IV. EFFECTS OF VARIOUS AMINo ACIDS ON UA Production IN THE SYNTheTIC MEDIUM

$\begin{array}{lcc} & \text { UA. produced } & \begin{array}{c}\text { max growth } \\ \text { rate* }\end{array} \\ \text { L-phenylalanine } & 170(\mathrm{r} / \mathrm{ml}) & 0.33 \\ \text { DL-ornithine } & 270 & 0.31 \\ \text { DL-methionine } & 160 & 0.28 \\ \text { L-tryptophane } & 160 & 0.27 \\ \text { L-tyrosine } & 210 & 0.30 \\ \text { L-hydroxyproline } & 170 & 0.26 \\ \text { DL-threonine } & 160 & 0.30 \\ \text { DL-leucine } & 140 & 0.10 \\ \text { DL-isoleucine } & 220 & 0.28 \\ \text { L-lysine } & 190 & 0.25 \\ \text { L-arginine } & 260 & 0.31 \\ \text { L-proline } & 200 & 0.30 \\ \text { glycine } & 170 & 0.18 \\ \text { L-serine } & 220 & 0.25 \\ \text { L-valine } & 200 & 0.25 \\ \text { L-cysteine } & 110 & 0.16 \\ \text { L-cystine } & 130 & 0.22 \\ \text { L-glutamic acid } & 300 & 0.33 \\ \text { L-asparatic acid } & 250 & 0.32 \\ \text { DL-alanine } & 220 & 0.28 \\ \text { L-glutamine } & 540 & 0.31 \\ \text { L-histamine } & 380 & 0.32 \\ \text { X-factor }(0.1 \mathrm{ml} .) & 750 & 0.32 \\ \text { Control } & 205 & 0.26 \\ \text { (Gra } & & \end{array}$

* Growth rate is measured with turbidimeter at $590 \mathrm{~m} \mu$. Incubation is carried out with $\mathbf{T}$ flask.

2) The results of studies on composition of culture media, showed that meat extract was essential for urocanic acid production and its optimal concentration was $5 \%$.

3) From the studies on synthetic media containing histidine, a factor (X-factor) in meat extract was assumed to play an important role for urocanic acid accumulation of B. subtilis.

4) $\mathrm{X}$-Factor is a ninhydrin positive substance and can be replaced partly by some amino acid like compounds such as L-glutamine or ornithine cycle members.

5) Histidase of $B$. subtilis var. is a new exo-type enzyme (opt. $\mathrm{pH} 8.5 \sim 8.8$ ), and urocanase is a endo-enzyme (opt. pH 7.0 7.5)

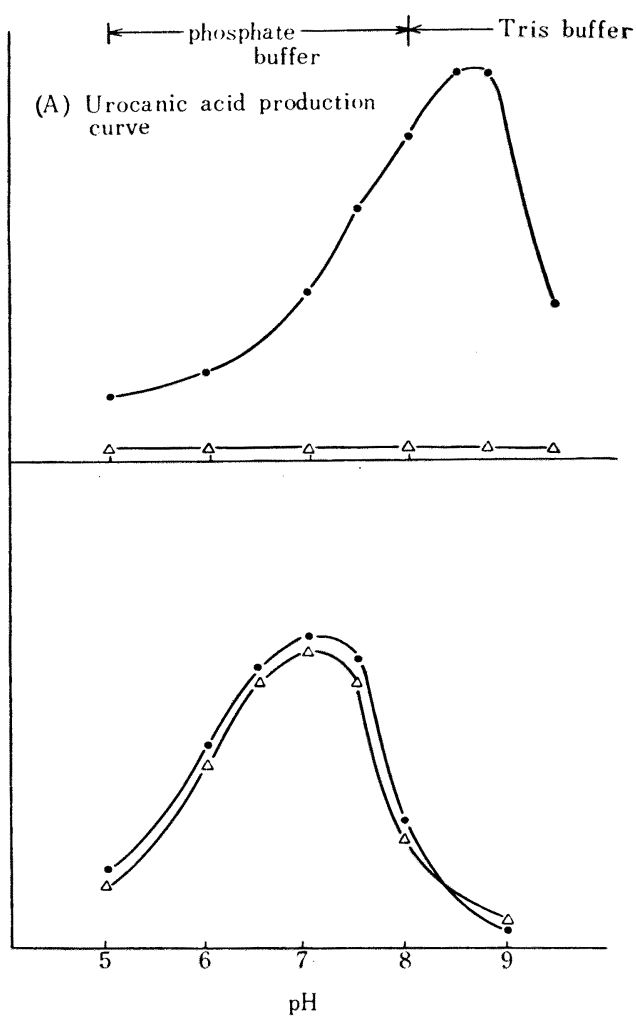

(B) Urocanic acid consumption curve

FIG. 6. Incubation of Resting Cell in Various" pH. Resting cells (as dried cell $5 \mathrm{mg}$ ) were incubated in $10 \mathrm{ml}$ buffer solution containing $0.2 \%$ L-histidine (A) or $0.2 \%$ urocanic acid (B) at $37^{\circ} \mathrm{C}:$

$$
\begin{aligned}
& \text { Resting cell of cultivation under presence of L- } \\
& \text { histidine? } \\
& \text { Resting cell of cultivation under presence, ?of } \\
& \text { urocanic acid. }
\end{aligned}
$$

which is rather weak in activity.

6) The noticeable accumulation of urocanic acid in bouillon medium by $B$. subtilis can be explained as the combined results of the following reasons; a) the optimal $\mathrm{pH}$ of histidase produced by $B$. subtilis lies between 8.5 and 8.8 and the $\mathrm{pH}$ of the broth rises to this range, b) urocanase produced by this organism is weak and the urocanic acid is scarcely degradaded, c) X-factor presented in meat extract stimulates the action of histidase.

Acknowledgements. The author is indebted 
to Professor Kei Arima of University of Tokyo for his invaluable advice and encouragement. He also wishes to express his sincere thanks to Drs. Mitiharu Miyazaki, Toshiro Fujisawa and Heiichi Sakai of our company and Laboratory for their encouragements throughout this work. 